\title{
Articles
}

\section{Euthanasia and the Ethics of Free Movement Law: The Principle of Recognition in the Internal Market}

\author{
By Barend van Leeuwen*
}

\begin{abstract}
The free movement provisions enable EU citizens to follow their own ethical preferences by going to a Member State that has made a different ethical choice from their home Member State. However, UK citizens who have assisted suicide or euthanasia abroad could be criminally prosecuted on their return to England. This possibility of a criminal prosecution constitutes a restriction on free movement. Nevertheless, the free movement provisions have so far not been used to challenge the English prohibition of euthanasia. The aim of this article is to show that, based on its ultimate aim, free movement law does have a legitimate role to play in ethical issues. The internal market is based on a principle of recognition, which forces Member States to engage with regulatory choices made by other Member States. This also applies to ethical issues. Member States are not required to justify the existence of different ethical choices. However, if they decide to restrict free movement, they have to be able to show that these differences in fact exist. This approach achieves a balance between the right of citizens to make their own ethical choices, and the ability of Member States to protect their legislation on ethical issues.
\end{abstract}

\footnotetext{
* Assistant Professor in EU Law at Durham Law School, United Kingdom. I am grateful to Rick Busscher, Justin Lindeboom, Robert Schütze, Eleanor Spaventa, Heleen Weyers, Floris de Witte and Jan Zglinski for the comments and discussions.
} 


\section{A. Introduction and Context}

In June 2018, the English Court of Appeal delivered another judgment in a case in which it had been argued that the Suicide Act 1961, which makes it illegal for doctors or family members to assist patients who would like to end their life, was incompatible with Article 8 of the European Convention of Human Rights ("ECHR"). ${ }^{1}$ After Diane Pretty, ${ }^{2}$ Debbie Purdy ${ }^{3}$ and Tony Nicklinson, ${ }^{4}$ Noel Conway -a terminally ill patient with Motor Neuron Diseasealso brought an unsuccessful challenge to the compatibility of the Suicide Act 1961 with the ECHR. As such, the Suicide Act 1961 remains a controversial piece of legislation in the UK. Attempts to introduce an Assisted Dying Bill in the UK Parliament have not been successful. ${ }^{5}$ This did not prevent Mr. Conway from bringing a new legal challenge to the Suicide Act 1961. Most of these cases had similar features: Debbie Purdy, Mr. Martin-a co-claimant in Tony Nicklinson's case-and Noel Conway each wanted to travel to Switzerland to commit suicide in the Dignitas clinic. However, they would not be able to travel without the assistance of their family members. These family members would risk a criminal prosecution on their return to the UK. The Director of Public Prosecutions ("DPP") would always assess whether a criminal prosecution was in the public interest. Although no family members have ever been prosecuted, ${ }^{6}$ the DPP has consistently refused to provide a guarantee to patients that their family members will not be prosecuted.

All legal challenges in the UK were based on the ECHR. In particular, the claimants argued that the Suicide Act 1961 breached their right to respect for their private life provided in Article 8 ECHR. Some also submitted that their right to life in Article 2 ECHR-interpreted as including the right to choose when they wanted to end their life-had been breached. Despite the obvious cross-border element to their cases, none of the claimants based their submissions on EU law-in particular, on free movement law. At first glance, this may have had something to do with the fact that Switzerland is not a member of the EU. Its free

\footnotetext{
${ }^{1} \mathrm{R}$ (on the application of Noel Conway) v Secretary of State for Justice [2018] EWCA (Civ) 1431.

${ }^{2} \mathrm{R}$ (on the application of Diane Pretty) v Director of Public Prosecutions [2001] UKHL 61.

${ }^{3}$ R (on the application of Debbie Purdy) v Director of Public Prosecutions [2009] UKHL 45.

${ }^{4} \mathrm{R}$ (on the application of Jane Nicklinson) v Director of Public Prosecutions [2014] UKSC 38.

${ }^{5}$ The House of Lords rejected the most recent proposal in September 2016. See Assisted Dying Bill [HL] 2016-17, Parliament.UK, http://services.parliament.uk/bills/2016-17/assisteddying.html (last visited Oct. 26, 2018).

${ }^{6}$ For a short history of the application of the Suicide Act 1961 in the UK, see A. McCann, Assisted Dying in Europe: A Comparative Law and Governance Analysis of Four Countries and Two Supranational Systems (2016) (Ph.D. thesis, University of Groningen).
} 
movement arrangements with the EU are technical and complicated. ${ }^{7}$ However, this explanation would be too simplistic. Moreover, if the reluctance to base their case on EU law was caused by the fact that Switzerland was the preferred destination of the patients, they could easily have avoided this by choosing another destination in the EU. Although it is true that the Swiss legislation is particularly convenient for patients who would like to commit suicide, because it literally allows patients to fly out to Switzerland to die there, euthanasia and assisted suicide are now lawful in several EU Member States. ${ }^{8}$ Patients could, for example, decide to move to the Netherlands, where physician-assisted suicide is lawful. The main difference with Switzerland is that, to receive assisted suicide in the Netherlands, patients would have to have established a treatment relationship with a Dutch doctor. ${ }^{9}$ This may not be easy, but it could be a solution for UK patients who would like to end their lives in a dignified manner. Cross-border movement of patients within the EU to receive euthanasia abroad is not unheard of. Each year, a number of German patients receive euthanasia or assisted suicide in the Netherlands. Against this background, it is surprising that none of the UK claimants have tried to rely on free movement law to challenge the compatibility of the Suicide Act 1961 with EU law.

In the internal market, EU citizens enjoy free movement rights. One of those rights is the right to freely receive services in another Member State. In principle, this right makes it possible for citizens to make their own ethical choices by going to a Member State where the legislation on a particular ethical issue is different from the legislation in their home Member State. An Irish student who is pregnant can travel to England for an abortion. A French tourist can visit a prostitute in Amsterdam. A Dutch patient who is a hypochondriac can travel to Germany for a total body scan. As a result, the free movement provisions have become a tool for individuals to follow their own ethical preferences. Most of the time, they are not punished for making a different choice from their home Member State. French tourists who have smoked cannabis in a coffee shop in Amsterdam are not going to be prosecuted on their return to France. This is different in the case of English patients who have travelled abroad for euthanasia or assisted suicide. Their family members could potentially be prosecuted on their return to the UK. This is a factor which makes it more difficult for patients to receive euthanasia or assisted suicide in another Member State. As a result, there is a restriction on their right to freely receive services. Such a restriction has to be justified and, therefore, the UK has to provide a ground of justification. This would not be sufficient, as the UK would also have to show that the restriction complied with the

\footnotetext{
7 For an explanation of the EU-Swiss relations and free movement, see supra note 6; see also A. McCann, Comparing the Law and Governance of Assisted Dying in Four European Nations, 2 EUR. J. OF COMP. L. AND GOVERNANCE 37 (2015).

8 See for a comparative perspective, J. Griffiths, H. Weyers \& M. AdAMS, EUthANASiA AND LAW In EUROPE (Hart Publishing 2008).

${ }^{9}$ Wet toetsing levensbeëindiging op verzoek en hulp bij zelfdoding (Termination of Life on Request and Assisted Suicide (Review Procedures) Act).
} 
proportionality test. Therefore, it is not too complicated to turn a sensitive ethical dilemma into a free movement case. However, the fact that none of the claimants in the assisted suicide cases in the UK have relied on free movement law shows that there is a general reluctance to rely on free movement law in ethical cases.

This paper will make two main arguments. First, free movement law has a legitimate role to play in ethical discussions, such as debates about whether euthanasia should be lawful. Objections to the involvement of free movement law in cases with a strong ethical dimension have not sufficiently focused on the ultimate aim of the free movement provisions. Second, free movement law can be applied in such a way that it respects the various ethical positions in the EU Member States while still doing justice to the aim of the free movement provisions. Respecting ethical diversity in the EU does not mean that national ethical choices should be protected from the involvement of free movement law. Ethical pluralism in the internal market is achieved by making different national ethical choices interact and engage with each other-not by insulating them from any external perspectives. Free movement law has an important role to play in creating a forum where this interaction can take place.

The starting point of the paper will be to explore and reject the objections to the involvement of free movement law in cases with an ethical dimension. The next step is to present a non-economic perspective on free movement law, which will be used to decide how free movement law should be applied to ethical cases. At the core of free movement law is a principle of recognition, which requires Member States to recognize and to engage with regulatory choices made by other Member States. To protect the effet utile of the free movement provisions, this principle of recognition should also be applied to ethical cases. Finally, a hypothetical case of an English patient who would like to travel to the Netherlands to receive euthanasia will be analyzed. This case will be used to show how the free movement provisions can be applied in such a way that a balance is struck between the right of Member States to protect their ethical positions and the right of individuals to make their own ethical choices.

\section{B. Free Movement Law as a Forum of Interaction}

Ethical questions are inherently personal questions. Decisions such as whether we would like to receive euthanasia or whether we would like to donate our organs are made on an individual basis. As a result, it is very difficult to reach consensus on ethical issues among a certain group of individuals. ${ }^{10}$ Nevertheless, Member States have to adopt legislation on ethical issues. This legislation is often disputed at the national level. The character of national legislation on ethical issues as a compromise explains why the EU is extremely

${ }^{10} \mathrm{C}$. Knill, The Study of Morality Policy: Analytical Implications from a Public Policy Perspective, 20 J. OF EUR. PUB. POL'Y 309 (2013). 
hesitant to get involved in ethical debates and to adopt an autonomous ethical position. The representational gap between the EU and its citizens is too significant for the EU to legitimately impose its ethical views. ${ }^{11}$ For example, it would not be legitimate for the EU to adopt legislation which provides that euthanasia should be lawful in all Member States. In the field of healthcare services, this reluctance is reinforced by the lack of competence of the EU to regulate healthcare services. ${ }^{12}$ This lack of competence is a legal tool to operationalize the distance between the EU and the citizens on moral and ethical issues. Two conclusions flow from this distance. First, it is not legitimate for the EU to impose one ethical view on the Member States ("euthanasia should be lawful"). Second, it is not legitimate for the EU to force one Member State to accept the ethical choice which has been made by another Member State ("the UK has to accept that if euthanasia is lawful in the Netherlands, it should also be lawful in the UK"). In the EU, mutual recognition is always based on mutual trust. There has to be a foundation for this trust. In the free movement of goods, the EU has created such a foundation by developing an elaborate regulatory framework to adopt European product standards. ${ }^{13}$ In EU criminal law, mutual trust is based on a presumption that all EU Member States comply with the same set of fundamental rights standards - whether based on the ECHR or on the Charter. ${ }^{14}$ This level of trust does not exist in the field of ethics. Moreover, this is a field in which the EU accepts that Member States have made very different choices and that these differences are legitimate. The task of the EU is to protect these differences rather than to eliminate them- "unity in diversity."

As a result of this starting point, free movement law has adopted a deferential approach to national ethical positions. The most obvious example of this deference can be seen in Grogan. ${ }^{15}$ The facts are well-known: Irish student associations distributed leaflets to students to provide information about the possibility of receiving abortion services in the UK. Abortion was prohibited by the Irish Constitution, while it was lawful in the UK. A private association attempted to enforce the prohibition by claiming that the Irish court should issue an injunction prohibiting the student associations from handing out these leaflets. When the student associations claimed that such an injunction would breach the right to freely provide services, a preliminary reference was made to the Court of Justice of

\footnotetext{
${ }^{11} \mathrm{~F}$. de Witte, Sex, Drugs \& EU Law: The Recognition of Moral and Ethical Diversity in EU Law, 50 COMMON MKT. L. REV. 1545, 1550-51 (2013).

${ }^{12}$ Article 168(7) TFEU; see T. Hervey \& J. Mchale, European Union Health LaW: Themes and Implications (Cambridge Univ. Press 2016).

13 See H. Schepel, The Constitution of Private Governance (Hart Publishing 2005); see also B. van LeEuWEn, European StANDARDISATION OF SERVICES AND ITS IMPACT ON PRIVATE LAW (Hart Publishing 2017).

${ }^{14}$ C. Janssens, The Principle of Mutual Recognition in EU LaW, pt. II (2013).

15 Case C-159/90 Society for the Protection of Unborn Children Ltd V Stephen Grogan and others, ECLI:EU:C:1991:378.
} 
the European Union ("the CJEU"). The CJEU held that the case fell outside the scope of the free movement provisions, because there was no economic link between the student associations and the abortion clinics in the UK. ${ }^{16}$ After all, the clinics did not pay the student association for distributing the leaflets. The CJEU's judgment has been criticized heavily from a legal point of view. ${ }^{17}$ Yet, the main message of the judgment was not about the substance of free movement law. It was moral: EU law does not want to get involved in this very sensitive ethical discussion. A technical argument about the scope of free movement law was used to avoid having to engage with the substance of the ethical choice. Similarly, because no restriction on free movement was found, Ireland did not have to provide a justification and show that the restriction was proportionate. A similar technique was used in Josemans, ${ }^{18}$ in which the policy of the city of Maastricht to prohibit the sale of soft drugs to citizens who were not resident in the Netherlands was challenged under the free movement provisions. In both cases, the CJEU used technical legal arguments to protect the national ethical choice from review under free movement law. These legal arguments were only a tool for the CJEU to make a more fundamental statement: it did not want to have to engage with fundamental and substantive ethical choices which had been made at the national level.

This deferential attitude of the CJEU is justified when the aim is to prevent EU law from imposing one ethical position on the Member State, or from imposing mutual recognition of national ethical choices. Nevertheless, these reasons are not good justifications to completely shield ethical cases from the application of free movement law. A clearer distinction should be made between positive integration, harmonization, and negative integration. While both approaches essentially share the same aim-improving the functioning of the internal market-they seek to achieve this aim in different ways. When the EU adopts harmonization in a particular field, one set of rules is provided that applies to all Member States. As a result, harmonization carries with it the risk that the EU might replace and harmonize ethical choices which have been made at the national level. Brüstle was about a directive in the field of intellectual property law, which prohibited Member States from issuing patents for inventions in which human embryos were used. ${ }^{19}$ The CJEU held that the concept of "human embryo" should be given an autonomous definition in EU law. As such, it has effectively harmonized what constitutes a human embryo under EU law. Since Member States have very different views on when a human embryo actually

\footnotetext{
${ }^{16}$ Id. $24-27$.

${ }^{17}$ See S. O'Leary, The Court of Justice as a Reluctant Constitutional Adjudicator: An Examination of the Abortion Information Case, 17 EUR. L. REV. 138 (1992); G. de Búrca, Fundamental Rights and the Reach of Community Law, 13 OXFoRd J. OF LEGAL STUD. 283 (1993); D. Curtin, Case C-159/90, The Society for the Protection of Unborn Children Ireland Ltd v. Grogan, Judgment of 4 October 1999, 29 COMMON MKT. L. REV. 585 (1992).

${ }^{18}$ Case C-137/09 Josemans v Burgemeester van Maastricht, ECLI:EU:C:2010:774.

${ }^{19}$ Case C-34/10 Brüstle v Greenpeace eV, ECLI:EU:C:2011:669.
} 
becomes a human embryo, in Brüstle, the CJEU essentially imposed one ethical position on the Member States. Similarly, there is a risk that through harmonization, the EU forces Member States to accept the ethical positions of other Member States. In Coman, ${ }^{20}$ the CJEU held that Member States that do not recognize same-sex marriages have to interpret the concept of "spouse" in the Citizen Rights Directive ${ }^{21}$ - which has not been defined in the Directive-in such a way that it applies to same-sex couples who have lawfully concluded a marriage in another Member State where same-sex marriages are allowed. This effectively leads to mutual recognition of same-sex marriages in the EU, and forces Member States to accept ethical choices which have been made by other Member States.

Negative integration is a different process. In a free movement case, the free movement provisions are used as a tool to confront one national regulatory choice with another national regulatory choice. This is an exercise in confrontation, which does not necessarily require EU law to adopt its own ethical position. The free movement provisions provide a platform where two different national choices are made to interact with each other. ${ }^{22}$ They give citizens a right to confront a Member State with regulatory choices that have been made in another Member State, and they force this Member State to interact and to engage with that regulatory choice. For example, if an English patient wanted to travel to the Netherlands to receive euthanasia, the English ethical position would be confronted with the Dutch ethical position. Free movement law acts as a catalyst, which elevates the English discussion about whether euthanasia should be lawful to a European forum, where the English ethical position has to interact with the Dutch ethical position. In such cases, the CJEU does not have to make an autonomous ethical choice-the choice which is made is between the English ethical position and the Dutch ethical position. If it is accepted that mutual recognition of national ethical choices is not legitimate, there is no risk that the involvement of free movement law would lead to the imposition of one ethical position at the European level. Therefore, in cases based on the free movement provisions, there is no risk that the CJEU would impose an autonomous ethical position on the Member States. Similarly, there is no risk that it would force Member States to recognize the ethical choices made by other Member States. The real objection to the involvement of free movement law in these cases is not that the CJEU would impose one ethical position on

\footnotetext{
${ }^{20}$ Case C-673/16 Coman and others v Inspectoratul General pentru Imigrari, ECLI:EU:C:2018:385.

${ }^{21}$ Article 2(2)(a) of Directive 2004/38/EC on the right of citizens of the Union and their family members to move and reside freely within the territory of the Member States; see C. Bell \& N. Baĉić Selanec, Who is a "spouse" under the Citizens' Rights Directive? The prospect of mutual recognition of same-sex marriages in the EU, 41 EUR. L. REV. 655 (2016).

22 See also L. Azoulai, The European Court of Justice and the duty to respect sensitive national interests, in JUDICIAL Activism at THE European Court of JUstice 167-87 (M. Dawson, B. de Witte \& E. Muir eds., Edward Elgar Publishing 2013).
} 
the Member States, but that the mediation exercise between two different national ethical positions would be performed in a biased way. ${ }^{23}$

This objection is directly based on the perceived aim of the free movement provisions. It is said that the free movement provisions are unable to perform the mediation exercise between different national ethical positions in a neutral way because of their inherent focus on economic integration. ${ }^{24}$ The free movement provisions are about trade, about market interests, about economic efficiency. Ethical issues should not be discussed in this forum, because they would be exposed to economic or efficiency-based reasoning. While it is right to say that ethical issues should not be decided on the basis of economic considerations, the sole fact that the internal market is a "market" should not in itself be a justification to prevent ethical issues from being discussed in free movement cases. The market has always been a forum for ethical debates. ${ }^{25}$ The main question is how the market deals with ethical issues. The CJEU has shown that it is able to apply the free movement provisions to national ethical positions without exposing these positions to efficiency-based reasoning. If a Member State is relying on a justification for a restriction on free movement which is genuinely non-economic and based on the protection of their ethical position, the application of the free movement provisions does not suddenly turn such a case into a case about economic efficiency. In Omega, ${ }^{26}$ Germany justified a restriction on the right to freely provide services on the basis of the protection of the right to human dignity. The German authorities had adopted a specific interpretation of the right to human dignity, which meant that they wanted to be able to prohibit a laser-gaming concept developed in the UK, in which participants aimed to eliminate each other. The protection of human dignity was accepted as a justification under the umbrella of public policy. The CJEU focused on the level of protection that Germany provided to the right to human dignity-or rather the German interpretation of the concept of human dignity - visà-vis the protection of the right to human dignity provided in the UK. The proportionality test also focused on what was suitable and necessary from the perspective of the German ethical position. ${ }^{27}$ Economic considerations played no role in this assessment. In SaynWittgenstein, ${ }^{28}$ Austria wanted to prevent an Austrian citizen from using a royal title which she had lawfully acquired in Germany. This was based on the Austrian Constitution, which

\footnotetext{
${ }^{23}$ Supra note 11, pp. 1568-70.

${ }^{24}$ A. Somek, The Argument from Transnational Effects I: Representing Outsiders through Freedom of Movement, 16 EUR. L.J. 315, 342 (2010).

${ }^{25}$ See M. Weber, The Protestant Ethic ANd the Spirit of CAPitalism (1930).

${ }^{26}$ Case C-36/02 Omega Spielhallen- und Automatenaufstellungs-GmbH v Oberbürgermeisterin des Bundesstadt Bonn, ECLI:EU:C:2004:614.

27 Id. 39.

${ }^{28}$ Case C-208/09 Ilonka Sayn-Wittgenstein v Landeshauptmann von Wien, ECLI:EU:C:2010:806.
} 
protected the right to equality among citizens. The reasoning of the CJEU focused on the differences in the Austrian and German protection of the right to equality, and on whether the restriction on free movement was suitable and necessary for Austria to protect its different approach to equality. ${ }^{29}$ In the case of an English patient who would like to travel to the Netherlands to receive euthanasia, the free movement provisions would put the English position on euthanasia vis-à-vis the Dutch position on euthanasia. As will be discussed in more detail below, the UK would probably rely on the protection of the right to life as a justification for the restriction on the right to freely receive services in the Netherlands. The question for the CJEU would be if it was suitable and necessary for the UK to keep open the possibility of prosecuting family members who have assisted suicide in another Member State to guarantee the level of protection that the UK has decided to give to the right to life. This would involve a comparison between the level of protection provided to the right to life in the UK and in the Netherlands. Again, no economic factors would have an impact on that assessment.

Overall, it is clear that the application of the free movement provisions in cases with an ethical dimension does not necessarily lead to an economics-based approach by the CJEU. Similarly, the free movement provisions do not force the CJEU -or the EU more broadly- to impose one ethical position on all Member States or to force Member States to accept the ethical choice made by another Member State. The free movement provisions can be applied in such a way that they are neutral to different national ethical positions. However, even if their application is neutral, it is still a different question whether the free movement provisions should be applied to genuinely non-economic or ethical issues. The answer to that question should depend on the aim of the free movement provisions. This is what will be discussed in the next section.

\section{The Non-Economic Foundations of Free Movement Law}

There are few theoretical approaches to free movement law in the context of the EU internal market. ${ }^{30}$ Those theoretical approaches that do exist focus primarily on the economic foundations of free movement law, and the economic rationale behind the creation of an internal market. ${ }^{31}$ As such, their focus has been on economic efficiency and market integration. Therefore, it is not surprising that the free movement provisions are often considered to have a predominantly economic purpose. With the exception of the development of EU citizenship, ${ }^{32}$ the non-economic dimensions of the free movement

\footnotetext{
${ }^{29} /$ d. $90-94$.

30 Most textbooks on free movement law do not really provide a more theoretical perspective. See, e.g., C. BARNARD, THE SUbSTANTIVE LAW OF THE EU, ch. 1 (2016).

${ }^{31}$ See, e.g., W. Molle, The Economics of European Integration (2006); J. Pelkmans, European Integration, Methods AND ECONOMIC ANALYSIS (1997).

32 See D. Kochenov, EU Citizenship ANd Federalism: The Role of Rights (2017).
} 
provisions have not been sufficiently explored from a theoretical perspective. ${ }^{33}$ If they have been explored, the approaches that were used adopted a political or philosophical perspective on the free movement provisions. For example, Alexander Somek ${ }^{34}$ and Floris De Witte ${ }^{35}$ have focused on the democratic legitimacy of the application of the free movement provisions to sensitive ethical issues. The aim of this paper is to provide a self-standing theoretical account of the free movement provisions. Free movement lawyers should not defer to economists or political scientists in doing so. They themselves should explore what they see as the theoretical foundations of free movement law. Such a non-economic perspective on the free movement provisions is necessary to do justice to the purpose of the free movement provisions. As will be shown below, an exclusively economic perspective on the internal market will ultimately go against the aim of the internal market. For that reason, it is also necessary to develop a non-economic theory of free movement law to make the free movement provisions and the internal market sustainable. This perspective is necessary to determine the appropriate role of the free movement provisions in ethical issues.

While there is no doubt that economic integration is one the main aims of the free movement provisions, economic integration has always been a tool to achieve a higher aim: to guarantee peace between the Member States and to improve the well-being of EU citizens. ${ }^{36}$ This means that the internal market has an important aim at the macro-level-to improve and maintain peaceful relations between Member States-as well as at the microlevel-to increase the well-being and welfare of EU citizens. The internal market does not only create a relationship between Member States, but also between the Member States and their citizens. EU citizens have always been at the center of the internal market. This can be seen in the application and the enforcement of the free movement provisions. After all, most free movement cases are brought by EU citizens, companies, or associations. The direct effect of the free movement provisions has enabled them to rely on the free movement provisions to challenge Member State legislation before the national courts. ${ }^{37}$ Most of the time, their purpose in relying on free movement law is to increase their own well-being. For that reason, it is often argued that free movement law places individual freedom above national solidarity. This results in a tension between the micro-aim and the macro-aim of the free movement provisions. However, those who criticize the

\footnotetext{
${ }^{33}$ But see M. MAduro, We the Court: The European Court of Justice AND the EuRopean EConomic Constitution (1998) (note the emphasis on economic constitution); see also, Freedom of movement under attack: Is it worth defending as the core of EU citizenship? EUI WORKING PAPERS (RSCAS) 2016/69 (focusing again on citizenship).

${ }^{34}$ Supra note 24; see also A. SOMEK, INDIVIDUALISM: AN ESSAY ON THE AUTHORITY OF THE EUROPEAN UNION (2008).

${ }^{35}$ Supra note 11.

${ }^{36}$ This is explicitly recognized in the structure of Article 3 TEU. See S. WEATHERILL, LAW AND VALUES IN THE EUROPEAN UNION 307 (2016).

${ }^{37}$ K. TUORI, EUROPEAN CONSTITUTIONALISM 149-50 (2015).
} 
individualistic nature of free movement law ignore the impact that the exercise of individual free movement rights has on the macro-level. Although the motive to exercise free movement rights may be selfish, it leads to a process of interaction between Member States. This process-regardless of its outcome-has an important impact on the relations between Member States, and on the relationship between Member States and EU citizens. Viking $^{38}$ and Laval, ${ }^{39}$ which have been heavily criticized for favoring free movement over social protection, ${ }^{40}$ were ultimately about forcing national labor law systems to take into account the conditions and characteristics of workers in other Member States. From a broader perspective, these cases were not just about companies that wanted to be able to pay lower wages or rely on the free movement provisions to force their Member States to engage in a deregulatory exercise. At a more fundamental level, they were an exercise in confrontation-some of the older Member States were confronted with the reality of the internal market after the process of enlargement in 2004. ${ }^{41}$ They were forced to re-orient and re-position themselves in that context. It was not possible for Finland and Sweden to ignore the position of workers in the new Member States. The older Member States were forced to engage with the position of workers from the new Member States, whose participation in the internal market they had to facilitate. A more national perspective on the protection of workers had to be replaced by a European internal-market based perspective on social protection.

One of the core foundations of the internal market is that EU citizens feel confident that free movement is able to improve their well-being. As such, the functioning of the internal market is conditional on the trust placed by EU citizens in its existence. For this trust to be sustainable, it is essential that EU citizens understand and support the connection between free movement law, peace, and the well-being of EU citizens. This is where the internal market of today is encountering serious problems. The connection between, on the one hand, peace and well-being of EU citizens and, on the other hand, economic integration as a tool to achieve these aims is not sufficiently obvious anymore to many EU citizens. The aim and the tool of the internal market have become disconnected. Two main reasons for this development can be identified. First of all, economic integration as a principle to justify the existence of the internal market has become too technical and too

\footnotetext{
${ }^{38}$ Case C-438/05 International Transport Workers' Federation v Viking Line ABP, ECLI:EU:C:2007:772.

${ }^{39}$ Case C-341/05 Laval un Partneri Ltd v Svenska Byggnadsarbetareförbundet, ECLI:EU:C:2007:809.

${ }^{40} \mathrm{~J}$. Malmberg \& T. Sigeman, Industrial Action and EU Economic Freedoms: The Autonomous Collective Bargaining Model Curtailed by the European Court of Justice, 45 Common MKT. L. ReV. 1115 (2008). For a more recent overview, see VIKING, LAVAL AND BEYOND (M. Freedland \& J. Prassl eds., 2014).

${ }^{41}$ L. Azoulai, The Court of Justice and the Social Market Economy, 45 Common MKT. L. REv. 1335 (2008); B. van Leeuwen, An Illusion of Protection and an Assumption of Responsibility: The Possibility of Swedish State Liability after Laval, 14 CAMBRIDGE YeARBOOK OF EUR. LEGAL STUd. 453 (2012).
} 
technocratic. ${ }^{42}$ This has become particularly obvious after the financial crisis. ${ }^{43}$ The measures which the EU had to take to protect the functioning of the internal market after the financial crisis were of a highly technocratic nature. Decisions were taken at a certain distance from the EU citizens, who did not really have a chance to get involved in the process. The EU adopted various packages of rules and reforms which had a direct and significant impact on the economies of the Member States. Furthermore, the enlargement of the EU has resulted in more significant differences in regulatory standards in the various Member States. Again, the benefits of these processes of enlargement are not sufficiently obvious to EU citizens. ${ }^{44}$ This has resulted in a process where EU citizens have distanced themselves from the internal market. Although the motives of the majority of UK citizens who voted in favor of Brexit were very diverse, a lack of trust in the ability of the internal market to improve their well-being was certainly one of them. A second reason for the disconnection between economic integration and peace is more social. The concept of peace as the foundational principle of the internal market has become too abstract for citizens to support the existence of the internal market. There are very few EU citizens left who have experienced war or armed conflict. For the younger generations of EU citizens, peace is an abstract concept that does not have anything to do with the reality of their day-to-day life. Again, the inability to understand and appreciate the necessity of the internal market to guarantee peace between Member States threatens the core of the internal market.

The disconnection between the aim-peace and well-being-and the tool-economic integration-of having an internal market can only be repaired by creating a tool that re-connects free movement law to peace and well-being. This is why a non-economic perspective on free movement law is essential. As was shown in the section above, the application of the free movement provisions leads to a process of interaction and confrontation between Member States. This process of negative integration provides an appropriate forum to force Member States to engage with each other's ethical choices. Interaction between Member States and EU citizens solely on economic issues is not sufficient to guarantee the trust of EU citizens in the internal market. The internal market also has to provide a forum for interaction on non-economic issues. For that reason, to protect the aim of the free movement provisions, free movement law has to play a role in ethical debates. The next section will discuss how this role can best be played.

\footnotetext{
${ }^{42}$ N. Scicluna, Politicization without democratization: How the Eurozone crisis is transforming EU law and politics, 12 INT'L J. OF CONST. L. 545 (2014); see also G. Majone, From Regulatory State to a Democratic Default, 52 J. of COMMON MKT. STUd. 1216 (2014).

${ }^{43}$ See Constitutional Change through Euro-Crisis Law (T. Beukers, B. de Witte \& C. Kilpatrick eds., 2017).

${ }^{44}$ See The Legitimacy of the European Union After Enlargement (J. Thomassen ed., 2009).
} 


\section{The Principle of Recognition in the Internal Market}

The non-economic foundations of free movement law can be found in the way in which the free movement provisions limit the sovereignty of Member States. This limitation of sovereignty is crucial to achieve the aim of the free movement provisions-to guarantee peace between Member States and to improve the well-being of citizens. This is not only achieved by subjecting the legislation of Member States to the rationale of economic integration, but also by the process through which free movement cases are assessed. This is a tool which is independent from the economic aim of the free movement provisions. Every case in which the free movement provisions are used to assess national legislation involves a process of interaction between Member States. It limits the sovereignty of the Member States by forcing them to engage with the regulatory choice of another Member State. This process is fundamental to the application of the free movement provisions. It can be found across the spectrum of free movement law. Member States have to take into account how goods have been produced in another Member State. ${ }^{45}$ Member States have to substantively assess the qualifications of workers who have been trained in another Member State. ${ }^{46}$ Being a member of the internal market means that Member States cannot deliberately close their eyes to what is happening in other Member States. This does not mean that the internal market has become one regulatory space without any internal borders. However, if Member States decide to create internal borders by restricting free movement, they have to do this on the basis of an assessment of how the regulatory choice in another Member State relates to the regulatory choice which they have made. This process of engagement limits the sovereignty of the Member States, because they are being forced to interact with the regulatory choice which has been made in another Member State.

Therefore, the free movement provisions are based on what could be described as a principle of recognition. Member States have to acknowledge the existence of different regulatory choices in the internal market and have to engage with these differences. The result of this comparative exercise is in no way determined by the free movement provisions - there is no obligation as to the outcome. ${ }^{47}$ However, there is an obligation as to the process through which Member States reach this result-they have to substantively engage with this regulatory choice made by another Member State. In certain fields of the

\footnotetext{
45 Case C-120/79 Rewe-Zentral AG v Bundesmonopolverwaltung für Branntwein (Cassis de Dijon), ECLI:EU:C:1979:42.

46 Case C-340/89 Irene Vlassopoulou V Ministerium für Jutstiz, Bundes- und Europaangelegenheiten, ECLI:EU:C:1991:193.

${ }^{47}$ For a more outcome-based perspective, see J.H.H. Weiler, Fundamental Rights and Fundamental Boundaries: Common Standards and Conflicting Values in the Protection of Human Rights in the European Legal Space, in AN IDENTITY FOR EUROPE: THE RELEVANCE OF MULTICULTURALISM IN EU CONSTRUCTION 73-101 (R. Kastoryano ed., 2009).
} 
internal market, the principle of recognition has been upgraded to mutual recognition. ${ }^{48}$ This means that Member States are expected to recognize the regulatory choice made by another Member State as their own: "Your regulatory choice has become my regulatory choice." As has already been discussed above, mutual recognition is based on a strong notion of trust between the Member States. Trust is one of the ultimate ways to recognize what is happening in another Member State. This notion of trust does not come out of thin air. Usually, Member States trust each other because there has already been a significant amount of harmonization in these areas. With mutual recognition, Member States are supposed to trust each other because they recognize that the differences in their legislation are minimal. It is clear that in certain areas of the internal market, the application of the principle of mutual recognition is based on a fiction of trust. For example, this can be seen in the area of criminal law and asylum and immigration. ${ }^{49}$ It is questionable whether Member States really trust each other's criminal justice systems. Nevertheless, EU law has imposed a very strong presumption of regulatory equivalence, which imposes a high evidential burden on Member States that want to argue that the regulatory choice made by another Member State does not comply with the regulatory standards. ${ }^{50}$ Crucially, in such cases, mutual recognition is no longer required because the other Member State does not comply with the underlying EU law standards (such as product standards or fundamental rights standards). In the case of ethical issues, there are no such underlying EU standards. This reinforces the argument that mutual recognition has no role to play in the field of ethics.

In the absence of mutual recognition and mutual trust, the core of the principle of recognition in the internal market is still effective. This requires Member States to engage with the regulatory choice of another Member State. If a restriction on free movement has been identified, the first step for the Member State is to justify this restriction..$^{51}$ The justification stage is essentially about why the Member State has made a different regulatory choice from another Member State. The next step is for the CJEU to assess the proportionality of the restriction. ${ }^{52}$ The focus of the proportionality stage is on how the

\footnotetext{
48 Supra note 14; see also K. Nicolaïdis, Trusting the Poles? Constructing Europe through Mutual Recognition, $14 \mathrm{~J}$. OF EUR. PUB. POL'Y 682 (2007); K. Nicolaïdis \& G. Shaffer, Transnational Mutual Recognition Regimes: Governance Without Global Government, 68 L. AND CONTEMP. PROBS. 263 (2005).

${ }^{49}$ E. Brouwer, Mutual Trust and the Dublin Regulation: Protection of Fundamental Rights in the EU and the Burden of Proof, 9 UtRECHT L. ReV. 135 (2013); see also A. Willems, Mutual Trust as a Term of Art in EU Criminal Law: Revealing its Hybrid Character, 9 EUR. J. OF LEGAL STUD. 211 (2016).

${ }^{50} \mathrm{E}$. Brouwer cited supra note 49; see also H. Battjes \& E. Brouwer, The Dublin Regulation and Mutual Trust: Judicial Coherence in EU Asylum Law?, 8 REVIEW OF EUROPEAN AdMINISTRATIVE LAW 183 (2015).

51 See Exceptions from EU Free Movement LaW (P. Koutrakos, N. Nic Shuibhne \& P. Syrpis eds., 2016).

52 Id.; see also N. Nic Shuibhne \& M. Maci, Proving Public Interest: The Growing Impact of Evidence in Free Movement Law, 50 CoMmon MKT. L. REV. 965 (2013).
} 
Member State has decided to make a different regulatory choice. In cases which involve more sensitive issues, such as ethical issues, the CJEU will be less rigorous in the assessment of why and how a Member State has made a different regulatory choice from another Member State. It will provide a broad margin of discretion to Member States. ${ }^{53}$ Nevertheless, there is one aspect on which the CJEU will not be lenient: the why and how steps only arise if there is a genuine difference between the regulatory choices made by the Member States. They have to be able to establish that their regulatory choice is in fact different from the choice which has been made by the other Member State. Free movement law does not accept a superficial argument about this difference-Member States have to be able to prove that their legislation is different. In order to be able to do this, they have to substantively engage with the regulatory choice made by the other Member State. This is the absolute minimum that is required by the principle of recognition in the internal market.

This minimum requirement also applies to ethical or moral choices made by Member States. If they are unable to establish that they have made a different ethical choice, Member States cannot justify restrictions on free movement. This is clear from Conegate. ${ }^{54}$ Some UK companies tried to import sex dolls which had been manufactured in Germany. The dolls were seized by UK customs authorities because they were considered to be contrary to the UK's public morality. However, similar dolls were already manufactured and sold in the UK. As such, the difference in the level of public morality protection between the UK and Germany did not in fact exist. The UK could not rely on public morality to impose import restrictions on these sex dolls. Member States cannot simply pretend or assume to have made a different ethical choice from another Member State-they have to prove that there is a genuine difference in ethical positions. This requires a substantive engagement with the ethical choice made by the other Member State. A similar approach can be seen in Jany, ${ }^{55}$ in which the Dutch authorities treated prostitutes from other Member States differently from Dutch prostitutes. In all free movement cases with an ethical dimension in which the CJEU has accepted that the restrictions on free movement were justified, there was no doubt that the Member State which restricted free movement had genuinely made a different ethical choice. As was already argued above, in Omega, for historical reasons, the German authorities had adopted a much stricter interpretation of the right to human dignity than the UK authorities. ${ }^{56}$ Similarly, in Sayn-Wittgenstein, noble or royal titles were prohibited in Austria, while in Germany, families were still allowed to

\footnotetext{
${ }^{53}$ See S. Weatherill, The Internal Market AS A Legal Concept ch. 11 (2017).

54 Case C-121/85 Conegate Limited v HM Customs and Excise, ECLI:EU:C:1986:114; see A. Tryfonidou, The Federal Implications of the Transformation of the Market Freedoms into Sources of Fundamental Rights for the Citizen, in EU Citizenship AND Federalism: The Role OF Rights 316-40 (D. Kochenov ed., 2017).

${ }^{55}$ Case C-268/99 Aldona Jany and others v Staatssecretaris van Justitie, ECLI:EU:C:2001:616.

56 Supra note $26,32-33$
} 
use these titles - at least as a part of their last name. ${ }^{57}$ The restrictions on free movement were based on genuine differences in the ethical choices which had been made in different Member States. It was on that basis that they were accepted by the CJEU.

In Conegate, the principle of recognition prevented a Member State from relying on a ground of justification. In other cases with a more complicated factual background, the principle of proportionality is the more appropriate tool to assess whether a Member State has adopted an ethical position which is genuinely different from another Member State. More precisely, the necessity test should be used to assess the differences between ethical positions. A restriction on free movement is only necessary if the level of protection provided to that ethical choice is different from the level of protection provided in another Member State. As such, the necessity test should force a Member State to compare its own ethical position with the legislation of another Member State. This would normally involve a comparison of the relevant national legislation. This assessment has to be carried out by the Member State imposing the restriction. Again, free movement law does not require a particular outcome. However, it does require that Member States can prove that they have actually substantively engaged with the ethical position in the other Member State. Free movement law should provide a broad margin of discretion as to the result of the comparison, but the process of comparison has to take place. In the terminology used by Floris de Witte, such a test would probably be considered a substantive proportionality test. ${ }^{58}$ After all, it forces Member States to engage with the substance of the regulatory choice made by another Member State. However, it is important to note that the substance of the proportionality test is determined entirely by the ethical position of the Member State. It would not be based on any economic or efficiency-based considerations.

De Witte has argued strongly that, to respect the differences in ethical positions in the EU, free movement law should only impose a procedural proportionality test. Such a proportionality test would focus exclusively on the internal consistency and transparency of the ethical choice made by the Member State. ${ }^{59}$ It would not impose any obligation on Member States to engage with the ethical positions of other Member States. Such a vision of protecting ethical pluralism in the internal market is fundamentally inconsistent with how the principle of recognition seeks to achieve ethical pluralism in the internal market. $A$ proportionality test which only adopts an internal perspective is not genuinely pluralisticit allows Member States to ignore different ethical positions in the internal market. This principle of recognition requires at least a substantive engagement with different ethical positions. It achieves and protects ethical pluralism by explicitly forcing Member States to

\footnotetext{
${ }^{57}$ Supra note 28,74 .

58 Supra note 11 , pp. 1566-70.

${ }^{59} \mathrm{Id}$. at 1570-75. For a similar approach, see J. Mulder, Responsive Adjudication and the 'Social Legitimacy' of the Internal Market, 22 EUR. L.J. 597, 610-12 (2016).
} 
determine the differences between them. In conducting this exercise, Member States should be given a margin of discretion in determining whether and to what extent their ethical positions are different. Such a comparative process is what EU citizens can expect from free movement law as a forum of interaction. Importantly, this does not mean that Member States are required to justify the existence of different ethical positions. They are only required to establish that these differences exist. On that basis, the principle of recognition achieves a balance between the right of Member States to protect their ethical positions and the right of citizens to make their own ethical choices. The final section of this paper will return to the topic of euthanasia and will analyze how the principle of recognition should be applied in the case of an English patient who would like to receive euthanasia in the Netherlands.

\section{E. The Application of the Principle of Recognition in the Field of Euthanasia}

In this final section, a hypothetical case will be discussed to analyze how the principle of recognition would be applied in the case of an English patient who would like to travel to the Netherlands to receive euthanasia or assisted suicide. It will be shown what the free movement provisions would require from Member States in such a case. ${ }^{60}$

Anna is an English citizen with a very aggressive form of bowel cancer. She has been treated for a number of years. Nonetheless, her treatment has been unsuccessful and her doctors have confirmed that there is nothing more they can do. They do not know how much longer Anna will live. Anna is suffering unbearably and spends most of her time in bed. She is under heavy medication to relieve the intense pain. Because she knows that there is no prospect of improvement, she would like to end her life in a dignified way. Her doctors have explained to her that they are unable to help, because euthanasia and assisted suicide are prohibited in the UK. In the newspaper, Anna reads about the End of Life Clinic in The Hague. ${ }^{61}$ This clinic is specialized in providing euthanasia and assisted suicide in very complicated cases in which the doctors who are treating a patient are unable or unwilling to provide euthanasia. Anna has a number of online and telephone consultations with the doctors who are working in the clinic. They confirm that Anna fulfills the requirements under Dutch law to receive euthanasia or assisted suicide. She is suffering unbearably and there is no prospect of improvement of her medical situation. However, the End of Life Clinic only treats patients who are residents of the Netherlands. Therefore, she is exploring the option of moving to the Netherlands for the last months of her life. Anna is unable to travel alone and she would need the assistance of her husband.

\footnotetext{
${ }^{60}$ For a discussion of a hypothetical case involving the UK and Switzerland, see A. McCann, supra note 7.

${ }^{61}$ See LEVENSEINDEKLINIEK, www.levenseindekliniek.nl (last visited Oct. 27, 2018). For more background, see Angela Neustatter, Assisted Dying: How Does it Work in a Dutch End-of-Life-Clinic?, GUARDIAN (Sept. 11, 2015), https://www.theguardian.com/lifeandstyle/2015/sep/11/assisted-dying-dutch-end-of-life-netherlandsunbearable-suffering.
} 
Her husband is worried that, on his return to England, after Anna has received euthanasia in the Netherlands, he could be prosecuted for having assisted suicide or euthanasia abroad. English criminal law asserts extraterritorial jurisdiction in that respect. ${ }^{62}$ Anna does not want to do anything that might put her husband at risk of a criminal prosecution. She asks the Director of Public Prosecutions ("DPP") to guarantee that her husband would not be prosecuted. The DPP refuses to do so and Anna brings an action before the Administrative Court. She claims that the refusal of the DPP to provide a guarantee of nonprosecution constitutes a restriction on her right under Article 56 TFEU to freely receive healthcare services in the Netherlands.

The first question for the Administrative Court would be to assess whether there was a restriction of Article 56 TFEU. The test is to see whether the national legislation makes it more difficult or less attractive for Anna to receive services in the Netherlands. ${ }^{63}$ The precise obstacle in this case is the refusal of the DPP to guarantee that Anna's husband would not be prosecuted. This refusal is making it more difficult for Anna to travel to the Netherlands to receive healthcare services, because she does not want to expose her husband to a risk of a criminal prosecution. That risk in itself is sufficient to establish a restriction of Article 56 TFEU. Even though it is unlikely that Anna's husband would be prosecuted, there would be an investigation into his case, which would take a certain period of time. The DPP has issued guidelines which set out several factors tending in favor and against a criminal prosecution. ${ }^{64}$ On that basis, it could be argued that Anna's husband would be able to assess the likelihood of a criminal prosecution and would be able to conclude that such a prosecution is unlikely. However, the uncertainty would still exist, and it is this uncertainty which constitutes a restriction on Anna's free movement rights. The UK would be required to justify this restriction. It would probably do so on the basis of the protection of the right to life, which is protected by Article 2 ECHR and Article 2 of the Charter of Fundamental Rights. In particular, by prohibiting euthanasia and assisted suicide, the UK aims to protect vulnerable citizens from undue pressure to end their lives. The protection of the right to life would fall under public policy, which is one of the Treaty justifications in Article 63 TFEU. ${ }^{65}$ The UK could also make a more general argument that the justification is based on the aim to protect the application of English criminal law. This would again be a public policy justification. However, the substantive aim of the criminal law in this case is to protect the right to life. As a result, it is more likely that the UK would

\footnotetext{
62 See Coroners and Justice Act 2009 c. $25 \S 59$ (Eng.). For a discussion, see P. ARNell, LAW ACRoss Borders: The EXTRATERRITORIAL APPLICATION OF UNITED KINGDOM LAW (2012). For an ethical perspective on extraterritorial jurisdiction in assisted suicide or euthanasia cases, see I. GLENN COHEN, PATIENTS WITH PASSPORTS: MEDICAL TOURISM, LAW AND ETHICS 315-70 (2015).

${ }^{63}$ Case C-76/90 Manfred Säger v Dennemeyer \& Co Ltd, ECLI:EU:C:1991:331.

${ }^{64}$ Director of Public Prosecutions, Policy for Prosecutors in Respect of Cases of Encouraging or Assisting Suicide (February 2010) (updated October 2014).

${ }^{65}$ Supra note 53, pp. 137-39.
} 
want to rely on the protection of the right to life as the justification for the restriction on free movement.

The next step would be to assess the proportionality of the restriction. It would start with an assessment of the suitability of the restriction. Is it suitable to protect the right to life to keep open the possibility of prosecuting family members who have assisted euthanasia or suicide abroad? It could be argued that because no family members have in fact been prosecuted in the UK, the prohibition of assisted suicide is only a symbolic prohibition. Nevertheless, even if the prohibition is considered symbolic, it still achieves its purpose. Although certain UK citizens decide to ignore the prohibition, a significant number of patients stay in the UK because of the fear that their family members might be prosecuted. Therefore, the measure does achieve its deterrent aim and contributes to the protection of the right to life. The conclusion would be that the DPP's refusal is suitable. The final question would then be, whether the restriction was also necessary. In other words, is it necessary to keep open the possibility of prosecuting family members who have assisted suicide abroad in order to protect the right to life? This is where the principle of recognition requires that the UK engages with the ethical choice which has been made by the Netherlands. The starting point should be that it is only necessary for the DPP to keep open the possibility of a criminal prosecution if the way in which the Netherlands protects the right to life is different from the way in which the UK protects the right to life. This is the foundation on which all free movement cases with an ethical dimension have been decided. The Member State which is restricting free movement has to establish that it has made a different ethical choice.

In Anna's case, this means that the DPP would be required to compare the Suicide Act 1961 and the DPP Guidelines-including the factors tending in favor and against a prosecution-with the relevant Dutch legislation. ${ }^{66}$ The DPP would have to show that the way in which the UK protects the right to life is different from the way in which the Netherlands protects the right to life. As a result, he will have to assess how the right to life is protected under the Dutch legislation. Under free movement law, Anna does not have a right to claim a particular kind of outcome of this assessment, but she does have a right to force the UK to recognize and engage with the legislation in the Netherlands.

This approach to free movement cases with an ethical dimension strikes a balance between the UK's right to decide how to regulate euthanasia or assisted suicide, and Anna's right to freely make her own ethical decisions. ${ }^{67}$ Anna has a right to expect that the UK substantively engages with the ethical choice of another Member State, and that it establishes that a different ethical choice has been made. The UK remains autonomous in

\footnotetext{
${ }^{66}$ Wet toetsing levensbeëindiging op verzoek en hulp bij zelfdoding (Termination of Life on Request and Assisted Suicide (Review Procedures) Act).

${ }^{67}$ See also supra note 47.
} 
making its ethical choices, but in order to restrict free movement it has to show that it has adopted a different ethical position from the Netherlands.

\section{F. Conclusion}

The starting point of this paper was that the role which free movement law should play in ethical discussions has to be determined by the aim of the free movement provisions. The fundamental aim of the free movement provisions is non-economic. This also means that the free movement provisions have a role to play in discussions that are genuinely noneconomic, such as ethical debates. The application of the free movement provisions to ethical cases does not require the CJEU to adopt an autonomous ethical position at the EU level. Moreover, the CJEU has proved that it is able to apply the free movement provisions to cases with an ethical dimension without exposing them to economic or efficiency-based reasoning. The internal market provides a forum of interaction, which can and should be used by individuals to confront Member States with ethical choices made in other Member States. This exercise in confrontation is based on the principle of recognition. This principle forces Member States to engage with different regulatory and ethical choices in the internal market. This limitation of their sovereignty is necessary to achieve the aim of the free movement provisions.

The initial reaction of the skeptical reader may be that giving EU citizens a right to receive euthanasia in another Member State would only decrease the faith of citizens in the internal market. The point is: the principle of recognition does not give EU citizens such a right. It does not impose any kind of outcome - it only imposes an obligation on Member States to engage in a process of comparison. Member States are required to explore and define the ethical differences between them. They do not have to justify them and they certainly do not have to accept ethical choices made by other Member States. Free movement law establishes a dialogue between Member States on ethical issues. Based on its non-economic foundations, the function of the free movement provisions is to build bridges between different ethical positions in the EU. These bridges can be closed, or they can be opened. The frequency with which the bridges will be crossed from one Member State to another will depend on the willingness of Member States to open them and on the willingness of EU citizens to cross them. In any event, it is the task of free movement law to build the bridges. 